\title{
Vitamin D Receptor Gene TAQ 1 (rs 731236) PolymorphismIn Breast Cancer Patients ATH Adam Malik Hospital Medan and its Relationship with Histopathologygrading
}

\author{
Ika Waraztuty*1, Kamal Basri Siregar ${ }^{2}$ and Yahwardiah Siregar ${ }^{3}$ \\ ${ }^{1.3}$ Departement of Biomedical Sciences, Faculty of Medicine Universitas Sumatera Utara, Indonesia \\ ${ }^{2}$ Department of Oncology Surgery, H Adam Malik Hospital, Indonesia
}

Received: June 14, 2018; Published: June 26, 2018

*Corresponding author: Kamal Basri Siregar, Department of Oncology Surgery H Adam Malik Hospital, Medan, Indonesia

\begin{abstract}
Background: Breast cancer is the one of major cause of death in women especially in developing countries. In 2012 it was recorded nearly 522.000 deaths occurred due to this cancer. Taq 1 polymorphism is a silent SNPs called a genetic risk factor to breast cancer.
\end{abstract}

The Aim of the Study: To investigatethe relationship between of vitamin D-Taq1 receptor polymorphism gene (rs 731236) and histopathologic grading in breast cancer patients at Adam Malik Hospital. Medan.

Materials and Methods: Research subjects amounted to 53 breast cancer patients new diagnosed that have not received chemotherapy. DNA isolation from blood cells and gene amplification with PCR followed by RFLP using Taq1 restriction enzyme. Histopathologic grading data was obtained from the patient's medical records reviewed with anatomical pathologist.

Result: TT genotype was 92.5\% genotype TC 7.5\%. CC 0\% genotype with Hardy-Winberg Equilibrium (HWE) p=0.77.

Histopathologic grading was obtained grade 1 (9.4\%), grade 2 (49.1\%) and grade $3(41.5 \%)$.

Conclusion: Polymorphism of vitamin D-Taq1 receptor gene was not related to histopathologic grading in breast cancer patients at Adam Malik Hospital $(\mathrm{p}=1.000)$

Keywords: Breast Cancer TAQ1 Polymorphism; Histopathologic Grading; Vitamin D-Taq1; Histopathologic; Hardy-Winberg; Equilibrium; Exon; Intron; Cardiovascular; Osteoporosis; Cytosine; Nottingham Grading System; Chi-Square; Propensity; Immunohistochemistry; Histopathologic

\section{Introduction}

Breast cancer was one of most commonly occurred cancer in women in 2012. It was reported that 1.7 million (11.9\%) women worldwide diagnosed as breast cancer and 6.3 million women with breast cancer had survived for 5 years [1]. In 2012. 404.000 breast cancer cases occurred annually in Asian with incidence of 30 cases in every 100.000 women. Highest incidence was in China (46\%). Japan (14\%) and Indonesia (12\%) [2]. Risk factor of breast cancer is multi factorial. Among of which was nutrition. Vitamin D is a far soluble vitamin with wide range of function. Low vitamin D level was associated with some diseases such as diabetes Cardiovascular osteoporosis multiple sclerosis and cancer [3].

Imtiaz et al. [4] Study found that serum vitamin D level in breast cancer patients were lower $(9.3 \mathrm{ng} / \mathrm{ml})$ than control group (14.9ng/ml). Vitamin D deficiency occurred in $95.6 \%$ breast cancer patients. Similar result also stated by Janbabai et al. [5] which studied vitamin D levels in 200 breast cancer patients. They explained that $23.5 \%$ of breast cancer patients developed severe vitamin D deficiency and $37.5 \%$ developed mild deficiency. In its mechanism of action vitamin D needs a receptor to be transported into cells. Thirty one tissues had been identified to express vitamin D receptor. Including breast tissue; this indicates that cells in the tissues have potential to exert biological responses based on the number of vitamin D available [6]. 
Gene encoding vitamin D receptor was found in chromosome 12. That is $12 \mathrm{q} 13$.This gene had 9exon and 3intron with length approximately of $75 \mathrm{~kb}$. Taq1 (rs 731236) polymorphism occurred in exon 9. Polymorphism occurred was SNPs (single nucleotide polymorphism) where thymine (T) base was altered into cytosine (C) (cod on ATT become ATC). This base alteration is still encoding isoleucine therefore it is called as Silent SNPs $[7,8]$. Several studies had reported association of polymorphism of Taq1 gene with breast cancer incidence [9-11]. Despite that there is still few associating this with breast cancer characteristics. Especially histopathologic grading such study had never been conducted in Indonesia.

\section{Material and Methods}

\section{Study Group}

Each subject signed informed consent after being explained about the aim and benefit of the study.Subjects amounted to 53 breast cancer patients new diagnosed that have not received chemotherapy. All patients were diagnosed and treated between Oktober 2017 until March 2018 at the Department of Oncology Surgery H.Adam Malik Hospital.Medan.

\section{PCR-RFLP}

About 3cc blood sample was obtained from each subject. Sample was collected in EDTA tube then its plasma was separated. Isolated DNA was amplified by PCR method using Go Taq Green Master mix ( $\rightarrow$ Promega USA) by adding primer forward 5'-CAG AGC ATG GAC AGG GAG CAA-3' and primer reverse 5'- CAC TTC GAG CAC AAG GGG CGT TAG C-3'.Using Thermal Cycler. DNA was amplified under initial denaturation temperature $94^{\circ} \mathrm{C}$ for 3 minutes followed by 30 denaturation cycle at $94^{\circ} \mathrm{C}$ for 45 secondsannealing at $60^{\circ} \mathrm{C}$ for 60 seconds and elongation at $72^{\circ} \mathrm{C}$ for 90 seconds and last step at $73^{\circ} \mathrm{C}$ for 5 minutes [12]. PCR product was then cleaved by restrictive enzyme Taq1 $\rightarrow$ thermo scientific) using RFLP methods (restriction fragment lenght polymorphism). RFLP product would be electrophoreses in gel $2 \%$ for 90 minutes with voltage of 70 Volt. Using gel doc. electrophoreses result was visualized. TT homozygote showed band at $494 \mathrm{bp}$. CC homozygote showed band at $290 \& 204 \mathrm{bp}$ and TC homozygote showed band at 494. $290 \& 204$ bp (Atoum MF and Yasmeen MA.2017).

\section{Histopathologic Grading}

Histologic grading data was obtained from patients' medical record which was reviewed with anatomical pathologic specialist based on The Nottingham Grading System.

\section{Statistical Analysis}

All statistical analyses were conducted using SPSS 22.0. Normality test was conducted using Kolmogorov-Smirnov. The relationship between each factor was examined using Chi-Square testif the requirement was fulfilled. Else Fisher exact testwas used. Result with $\mathrm{p}$ value of less than 0.05 were considered as statically significant.

\section{Result}

Subject characteristics were age at diagnosis ranged between 40-49 years old (45.3\%). menopause status was 50.9\%. age at menopause 45-50 years old (59.3\%). Based on histopathologic grading there was $5(9.4 \%)$ subjects belonged to grade1.26 (49.1\%) subjects belonged to grade2 and $22(41.5 \%)$ subjects belonged to grade3. Invasive ductal carcinoma was most common type. Found in 50 (94.3\%) subjects. For molecular subtype Luminal A was $15 \%$. Luminal B 17\%. Her2 9.4\%. Basal like/triple negatif 4\%. The rest were unknown. Positive LVI was found only in 1.8\% (Table 1).

Table 1: Subject characteristics.

\begin{tabular}{|c|c|}
\hline Characteristics & n (\%) \\
\hline \multicolumn{2}{|l|}{ Age (years) } \\
\hline$<40$ & $6(11,3)$ \\
\hline $40-49$ & $24(45,3)$ \\
\hline $50-59$ & $14(26,4)$ \\
\hline $60-69$ & $7(13,2)$ \\
\hline$\geq 70$ & $2(3,8)$ \\
\hline \multicolumn{2}{|l|}{ Age at Menarche (years) } \\
\hline$\leq 13$ & $31(58,5)$ \\
\hline$>13$ & $22(41,5)$ \\
\hline \multicolumn{2}{|l|}{ Menopause Status } \\
\hline Premeopause & $26(49,1)$ \\
\hline Post Menopause & $27(50,9)$ \\
\hline \multicolumn{2}{|l|}{ HistopathologicGrade } \\
\hline Grade 1 & $5(9,4)$ \\
\hline Grade 2 & $26(49,1)$ \\
\hline Grade 3 & $22(41,5)$ \\
\hline \multicolumn{2}{|l|}{ Type } \\
\hline Ductal Carcinoma Insitu & $0(0)$ \\
\hline Lobular Carcinoma Insitu & $0(0)$ \\
\hline Invasive Ductal Carcinoma & $50(94,3)$ \\
\hline Invasive Lobular Carcinoma & $3(5,7)$ \\
\hline \multicolumn{2}{|l|}{ Molecular Subtype } \\
\hline Luminal A & $8(15)$ \\
\hline Luminal B & $9(17)$ \\
\hline Her2 & $5(9,4)$ \\
\hline Basal-like/Triple Negative & $4(7,5)$ \\
\hline Unknown & $27(50,9)$ \\
\hline \multicolumn{2}{|l|}{$\begin{array}{c}\text { Lymphovascular infiltration } \\
\text { (LVI) }\end{array}$} \\
\hline Positive & $1(1,8)$ \\
\hline Negative & $52(98,11)$ \\
\hline
\end{tabular}

Distribution frequency of TT homozygote genotype was 49 subjects (92.5\%). TC genotype was 4 subject(7.5\%) and there was no CC genotype. Total T allele obtained was $96.2 \%$ and C allele was 3.8\%. Hardy-Winberg Equilibrium (HWE) p=0.77 (Table 2) and (Figure 1) TT genotype group had histopathologic grading: Grade 1 for 5 (9.4\%) patients. Grade 2 for 24 (45.3\%) patients and Grade 3 for $20(37.7 \%)$ patients. While TC genotype group had histopathologic grading: grade 1 for $0(0 \%)$ patients. grade 2 for $2(3.8 \%)$ patients and grade 3 for 2 (3.8\%) patients. P-value for Fisher's exact testwas 1.000. This indicated that these data was not significant. with significance at 5\% (Table 3) and (Figures 2-4). 
Table 2: Distribution Frequency of Genotype and Allele of Taq1.

\begin{tabular}{|c|c|c|}
\hline Genotype/Allele & n (\%) & HWE \\
\hline TT & $49(92,5 \%)$ & $\mathrm{P}=0,77$ \\
\hline TC & $4(7,5 \%)$ & \\
\hline CC & $0(0 \%)$ & \\
\hline Allele & & \\
\hline T & $102(96,2 \%)$ & \\
\hline C & $4(3,8 \%)$ & \\
\hline
\end{tabular}

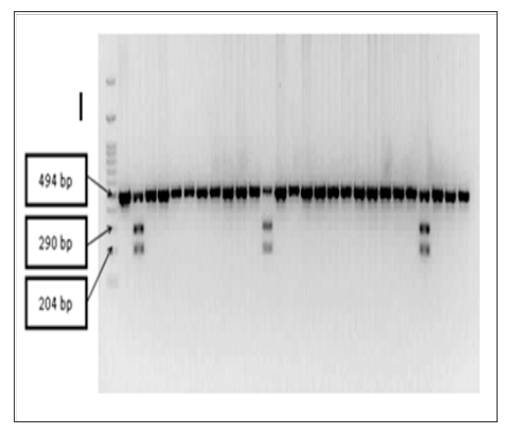

Figure 1: Visualization of PCR RFLP result using agarose gel $2 \%$.TT genotype resulted in band at $494 \mathrm{bp}, \mathrm{CC}$ genotype resulted in band at $290 \& 204 \mathrm{bp}$ and TC genotype resulted in band at 494, $290 \& 204 \mathrm{bp}$.

Table 3: Association of Taq1 Genotype and Histopathologic Grading.

\begin{tabular}{|c|c|c|c|c|}
\hline \multirow{2}{*}{ Genotype } & \multicolumn{3}{|c|}{ Histologic Grading } & \multirow{2}{*}{} \\
\cline { 2 - 4 } & Grade 1 & Grade 2 & Grade 3 & \multirow{2}{*}{ N } \\
\cline { 2 - 4 } & n (\%) & n (\%) & n (\%) & \\
\hline TT & $5(9,4)$ & $24(45,3)$ & $20(20,3)$ & 49 \\
\hline TC & $0(0)$ & $2(3,8)$ & $2(3,8)$ & 4 \\
\hline CC & - & - & - & \\
\hline \multirow{2}{*}{ T } & \multicolumn{2}{|c|}{ P = 1,000 } & N=53 \\
\hline
\end{tabular}

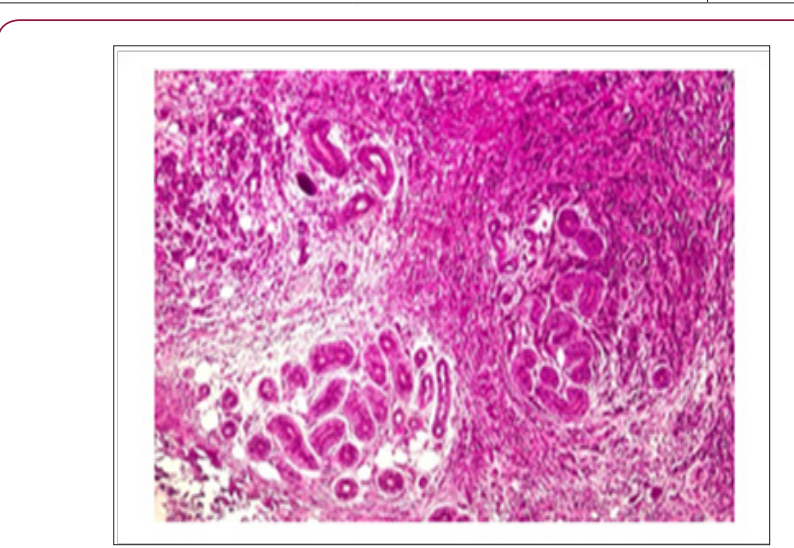

Figure 2: Histopathologic Grading-Grade1 (well differentiated).

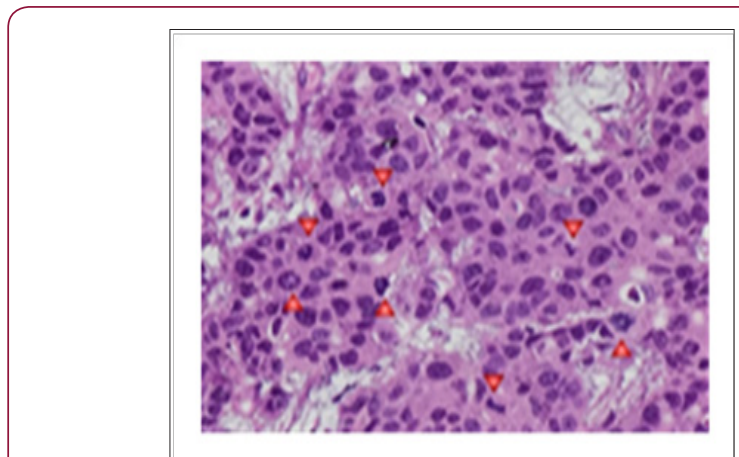

Figure 3: Histopathologic Grading-Grade 2 (moderate differentiated).

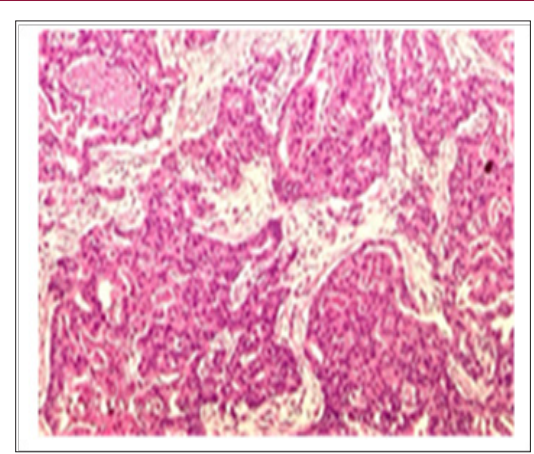

Figure 4: Histopathologic Grading-Grade 3 (poorly differentiated).

\section{Discussion}

Genotype distribution of gene Taq1 was varied across countries in this study majority of study subject had TT genotype (92.5\%). Breast cancer population in China was predominantly also had TT genotype (85.9\%). Meanwhile in breast cancer patients in Germany Australia and Jordanian had more TC genotype than other genotypes [12-15]. Polymorphism is a variation on genetic levels which could be inherited across generation therefore there would be more than $1 \%$ in population. Genotype frequency inherited would be constant in each generation at certain population under certain requirement that is: existing genotype had ability to survive and equal fertility. Mating occurred randomly there is no gene mutation. There is no migration and there is no natural selection [16].

To assess whether certain gene frequency is always constant and not evolving certain law was used. That is Hardy-Weinberg Law. In this study Taq1 gene variation was proven as polymorphism since according to the law of Hardy-Weinberg Equilibrium ( $P>0.05)$. $P$ value obtained was 0.77 . Studies about the relationship of Taq1 polymorphism and breast cancer gave contradictive result and varied widely. Atoum \& Al-Khatib study [12] showed that there was no significant differences between Taq1 genotype/allele frequency on breast cancer patient and control. So was Guo B et al. study [13] which stated that Taq1 polymorphism had no association with breast cancer.

Reimers et al. [17] study gave opposite result that polymorphism of CC genotype of Taq1 gene even had association $26 \%$ in reducing breast cancer risk. This was in line with this study where 
there is no CC genotype in breast cancer patients. Yet due to the absence of control we cannot assess its significance as protection factor. Mozzafarizadeh et al. [11] study indicated that TC genotype had correlation with the development of breast cancer $(\mathrm{p}<0.001$. $\mathrm{OR}=5.51 .0 .95 \mathrm{CI}-2.30-13.21)$. Another significant relationship also showed by Abbas et al. [9] but only in patients with positive estrogen receptor. El-Shorbagy et al. [10] study concluded that VDR TC genotype Taq1 variant ( $\mathrm{p}<0.005$. OR:3.71 95\%CI: 1.04-13.28) and TG genotype Apa1 ( $\mathrm{p}<0.001$. Or=7.05. 95\% CI: 2.02-24) had more propensity towards breast cancer.

Many studies had linked polymorphism of Taq1 with the incidence of breast cancer. Yet there is still few linking them with breast cancer characteristics. Especially histopathologic grading, Histopathologic grading was a differentiation marker of certain cell in tumor. Malignant tumor had varied manifestation from well differentiated cell until no differentiation. Assessment of differentiation grade histopathologically was introduced by Patley and Scarff by evaluating 3 tumor characteristics. This is tubule and gland formation pleomorphic nuclear cell and mitosis counting. This evaluation was subsequently modified by Elston and Ellis and called as The Nottingham Grading Systemwhich has been widely used until now to assess differentiation grade and outcome in patients with invasive carcinoma [18].

In this study subject with grade 2 had more percentage (49.1\%) than grade 1 (9.4\%) and grade $3(41.5 \%)$. This paralleled with Widodo et al. [19] with grade 1 percentage of $15.5 \%$. grade $244 \%$. and grade $340.5 \%$ [22]. Ng CH et al. [20] study comparing breast cancer histopathology between Dharmais Cancer Hospital. Indonesia with University Melaya Medical Centre. Malaysia also showed equal result where grade II was the most commonly found of breast cancer patients in both hospitals. But tumor with the lowest grade in Dharma is Cancer Hospital was higher (28\%) than University Melaya Medical Centre (11\%). In this study polymorphism of Taq 1 was not found had significant association with histopathologic grading in breast cancer patients. This study result was in parallel with El Shorbagy et al. [10] subject with TT variant had grade 1 as much as $(0 \%)$. grade $2(88.9 \%)$. and grade $3(11.11 \%)$. Meanwhile in TC variant subject with grade $1(3.08 \%)$. grade $2(86.1 \%)$ and grade $3(10.77 \%)$.

There was no CC variant. Insignificant results also found in histopathologic grading invasion of lymph and vascular estrogen and progesterone receptor. Structural and function alteration of vitamin D receptor (VDR) due to polymorphism of Taq 1 has not been elucidated. Insignificant relationship between polymorphism of Taq 1 and histopathologic grading obtained from this study was probably due to no alteration in structure and function of VDR by Taq 1 polymorphism therefore not affecting its action with vitamin D which could affect three determinant of histologic grading (genesis of breast duct and gland. pleomorphic nuclear cell. and mitosis count) To determine the effect of Taq 1 polymorphism to histopathologicgrading on molecular levels. We need to assess its relationship with protein/molecule expression involved in proliferation differentiation apoptosis. Angiogenesis process which affecting compo- nent of histopathologic grading assessment in immunohistochemistry of breast cancer tissue sample.

\section{Conclusion}

Polymorphism of vitamin D receptor gene Taq 1 is not associated with histopathologic grading of breast cancer.

\section{Ethic}

All procedures performed in studies involving human participants were in accordance with the ethical standards of the institutional and/or national research committee and with the 1964 Helsinki declaration and its later amendments or comparable ethical standards.This study has been approved by Health Study Ethic Committee Medical Faculty. Universitas Sumatera Utara. Approval number. 473/TGL/KEPK FK USU-RSUP HAM/2017.

\section{Study Explanation}

Characteristic data of study participant was shared data with another study authors (Astrid Siska Pratiwi. Melya Susanti. Ira Astuti dan Zakirullah). These authors studied these data in association with different variables.

\section{Acknowledgement}

We expressed our gratitude to all subjects participated and each part supporting and giving counsel so that this journal could be well-finished.

\section{References}

1. Bray F, Ren JS, Masuyer E, Ferlay J (2013) Global estimate of cancer prevalence for 27 sites in adult population in 2008. International J Cancer 132(5): 1133-1145.

2. Bhoo-Pathy N, Yip CH, Hartman M, DeviBC, Taib NA, et al. (2013) Breast cancer research in Asia: adopt or adapt Western Knowledge? European Journal of Cancer 49(3): 703-709.

3. Holick MF (2004) Vitamin D: Importance in the prevention of cancers, type1 diabetes, heart diseases and osteoporosis. The American Journal of Clinical Nutrition 79(3): 362-371.

4. Imtiaz Saba, Neelam Siddiqui, Aasim Muhammad (2012) Vitamin D deficiency in newly diagnosed breast cancer patient. Indian Journal Endocrinology and Metabolism 16(3): 409-413.

5. Janbabai Ghasem, Ramin Shekarriz, Homa Hasanzadeh, Mohsen Aarabi, Borhani SS (2016) A Survey on the relationship between serum 25-hydroxy vitamin D level and tumor characteristics in patient with breast cancer. International Journal of Hematology-Oncology and Stem Cell Research 10(1): 30-36.

6. Norman Anthony W (2008) From vitamin D to hormone D: fundamentals of the vitamin D endokrine system essential for good health. The American Journal Clinical Nutrition 88(2): 491-499.

7. Miyamoto Ken Ichi, Robert A Kesterson, Hironori Yamamoto, Yutaka Taketani, Eri Nishiwaki, et al. (1997) Structural organization of the human vitamin D reseceptor chromosomal gene and its promoter. Journal of Molecular Endocrinology 11(8): 1165-1179.

8. Uitterlinden AG, Fang Y, Van Merus JB, Pols HA, Van Leeuwen JP (2004) Genetics and biology of vitamin D receptor polymorphisms. Gene 338(2): 143-156.

9. Abbas S, Nieters A, Linseisen J, Slanger T, Easton DF, et al. (2003) Average risk of breast and ovarian cancer assosiated with BRCA1 or BRCA2 mutation detected in case series unselected for family history: a combined analysis of 22 studies. Journal Human Genetic 72: 1117-1130. 
10. El Shorbagy HM, Mahmoud NH, Sabet Salwa (2017) Association of vitamin D receptor gene polymorphism with breast cancer risk in egyptian population. Tumor Biology 39(10): p. 1-9.

11. Mozaffarizadeh H, Hakimian M, Salehi M, Moazam E, Behjati M, et al. (2017) The relationship between breast cancer and VDR Gene polymophisms. Archieves of Breast Cancer 5(1): 26-31.

12. Atoum Manar Fayiz, Yasmeen Mohammad Al Khatib (2017) Association between serum 25-hydroxy vitamin D concentration and Taq1 vitamin D receptor gene polymorphism among Jordania females with breast cancer. Chinese Medical Journal 130(9): 1074-1078.

13. Guo Bingjun, Jing Xin, Hu Xiaoqiao, Li Fan, Chen Xiaopin (2015) Association between vitamin $\mathrm{D}$ receptor gene polymorphism and breast cancer in a Chinese population. International Journal Experimental Medicine 8(5): 8020-8024.

14. Perna L, Butterbach K, Haug U, Schottker B, Muller H, et al. (2013) Vitamin D Receptor Genotype rs731236 (Taq1) and Breast Cancer Prognosis. Journal of American Association for Cancer Research 22(3): 437-442.

15. Curran JE, Vaughan T, Lea RA, Weinsten SR, Morrison NA dan Griffiths LR (1999) Assosiation of vitamin D reseptor polymorphism with sporadic breast cancer development. International J Cancer 83: 723-726.

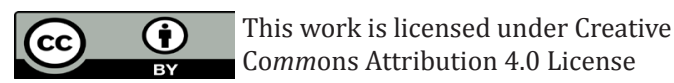

Submission Link: https://biomedres.us/submit-manuscript.php
16. Futuyma DJ (1998) Evolutionary Biology. ( ${ }^{\text {rd }}$ Edition). Sunderland, MA: Sinauer Associates, Chapter 9: 231-247.

17. Reimers LL, Crew KD, Bradshaw PT, Santella RM, Steck SE, et al. (2015) Vitamin D Related gene Polymorphism, Plasma 25-Hydroxyvitamin D, and breast cancer risk. Cancer Cause Control 26(2): 187-203.

18. Rakha EA, Reis Filho JS, Baehner F, Dabbs DJ, et al. (2010) Breast cancer prognostic classification in the molecular era: the role of histological grade. Breast Cancer Res 12(4): 207.

19. Widodo Irianiwati, Ery Kus Dwianingsih, Ediati Triningsih, Totok Utoro, Soeripto (2014) Clinicopathological features of Indonesian breast cancer with different molecular subtype. Asian Pacific Journal of Cancer Prevention 15(15): 6109-6113.

20. Ng CH, Pathy N Boo, Taib NA, Teh YC, Mun KS, et al. (2011) Comparision of breast cancer in Indonesia and Malaysia- A Clinico-Pathological Study between Dharmais Cancer Center Jakarta and University Malaya Medical Centre, Kuala Lumpur. Asian Pacific Journal Cancer prevention 12(11): 2943-2946.

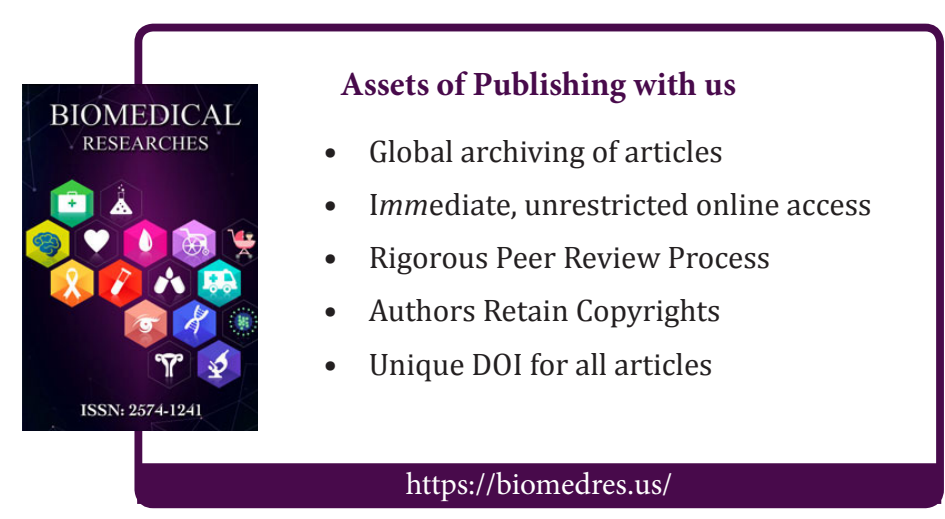

